\title{
Enhancing the Power Generation and COD Removal of Microbial Fuel Cell with ZrP-modified Proton Exchange Membrane
}

\author{
Liping Fan ${ }^{*}$, Lulu Zhang \\ Shenyang University of Chemical Technology, Shenyang, 110142, China \\ *E-mail: fanliping@syuct.edu.cn
}

doi: $10.20964 / 2018.03 .51$

Received: 20 November 2017 / Accepted: 12 January 2018 / Published: 5 February 2018

\begin{abstract}
An experimental system consisting of a dual chamber microbial fuel cell was constructed using simulated molasses wastewater as the anode substrate, carbon felt as the electrodes, Nafion membrane or modified Nafion membrane as proton exchange membrane. Zirconium phosphate and $\alpha$-zirconium phosphate were used to modify the Nafion membrane. By testing and analysis the output voltage and the COD removal rate of the microbial fuel cell, the effects of the zirconium phosphate and $\alpha$ zirconium phosphate on the performance of MFC were studied. Experimental results show that the power generation and water purification capacity of the MFC were improved significantly by modifying the proton exchange membrane with zirconium phosphate and $\alpha$-zirconium phosphate, Moreover, $\alpha$-zirconium phosphate modified exchange membrane has better effect. The steady output voltage of the microbial fuel cell with $\alpha$-zirconium phosphate is $0.0125 \mathrm{~V}$, COD removal is $79.25 \%$. The performance of microbial fuel cell was improved significantly by using zirconium phosphate modified exchange membrane.
\end{abstract}

Keywords: Microbial fuel cell; nano proton membrane; zirconium phosphate; power generation; wastewater treatment

\section{$\underline{\text { FULL TEXT }}$}

(C) 2018 The Authors. Published by ESG (www.electrochemsci.org). This article is an open access article distributed under the terms and conditions of the Creative Commons Attribution license (http://creativecommons.org/licenses/by/4.0/). 